doksologii nie tylko w połączeniu $\mathrm{z}$ innymi modlitwami, liczne odpusty. (,,Fidelibus, qui primo mane, meridie et vespere ter doxologiam Gloria Patri... devote recitaverint animo gratias agendi SS. Trinitati pro eximiis donis et privilegiis B. M. Virgini tributis conceditur: Indulgentia quingentorum dierum pro qualibet recitatione singulis praedictis diei partibus respondente. Indulgentia plenaria suetis conditionibus, si quotidie per integrum mensem ternam recitationem pia mente peregerint ${ }^{*}$. S. C. Indulg. 11. VII. 1815; S. Paen, Ap. 23. III. 1936). ${ }^{12}$ )

Ks. WŁADYSŁAW SMEREKA.

\title{
O NIEKTÓRYCH PODRĘCZNIKACH LITURGICZNYCH W DAWNYCH SEMINARIACH DUCHOWNYCH W POLSCE
}

W latach 1651 - 1864 pokaźna liczba seminariów duchownych pozostawała pod kierownictwem Zgromadzenia Księży Misjonarzy. W XVIII w. znaczna większość, bo ponad 20 seminariów było pod dyrekcją Zgromadzenia. Dawne seminaria duchowne w Polsce miały nastawienie raczej praktyczne. Nie kształciły one naukowców, ale przygotowywały duszpasterzy wiejskich, w myśl wskazań Soboru Trydenckiego, a zgodnie $\mathrm{z}$ celem misjonarskilm, zakreślonym przez św. Wincentego a Paulo.

To praktyczne nastawienie kazało profesorom w seminariach zwrócić szczególną uwage na syntetyczny wykład. Stąd rzadziej spotykamy traktaty naukowe, napisane przez profesorów misjonarskich. Częściej natomiast pisali i tłumaczyli oni podręczniki teologiczne, dotyczące wszystkich prawie przedmiotów wykładanych w seminarium. Niniejszy artykuł zwróci uwaşę na ważnicjsze podręczniki liturgiczne, oryginalne lub tłumaczone przez profesorów misjonarskich, a używane w licznych dawnych seminariach duchownych w Polsce.

\section{1. „MANUALE CAEREMONIARUM“.}

W roku 1764 ukazał się w Chełmnie na Pomorzu podręcznik p. t.: „Manuale Caeremoniarum Romanarum, ex libris Romanis maxime authenticis et authoribus in hac materia versatissimis, studio ac opera Presbyterorum Congregationis Missionis primum gallico idiomate con-

${ }^{12}$ ) „Preces et pia opera“, Roma 1936, str. 13. 
scriptum, recens vero in latinun sermonem conversum, et ad usum Ecclesiarum Poloniae accomodatum", Culmae in Prussia (1764), t. I-II, 2 wyd. Varsaviae, t. I. 1842, t. II. tamże 1819.

Podręcznik poiwyższy, jak w tytule zaznaczono, jest przekładem $z$ języka francuskiego. Jedną $z$ ulubionych tradycyj Zgromadzenia Księży Misjonarzy, przekazaną przez jego założyciela, jest troskliwe pielęgnowanie liturgii wraz $\mathrm{z}$ ceremoniami i śpiewu liturgiczno-kościelnego ${ }^{1}$ ). Na przestrzeni 300 -letniej swej historii Zgromadzenie zawsze wykazywało zrozumienie i ukochanie sprawy liturgicznej. Dał temu wyraz ks. Renat Almeras, drugi po św. Wincentym, przełożony generalny, wydając dla członków swego zgromadzenia podręcznik liturgiczny $^{2}$ ) $\mathrm{z}$ myślą zaprowadzenia jednolitego w całej kongregacji wykonywania obrzędów świętych. Podręcznik ks. Almeras, wydrukowany w Paryżu w r. 1662 p. t.: ,Manuel des cérémonies romaines qui s’observent dans les plus ordinaires offices divins, tiré des livres romains plus authentiques, et des plus intelligénts écrivains en cette matière (s. XXIV +428 ) przyjął się i znalazł zastosowanie w seminariach francuskich, kierowanych w znacznej większości przez misjonarzy.

Podręcznika tego używano po kościołach i w seminariach duchownych francuskich przez dwa prawie wieki następne. Był równiè̇ w powszechny'm użyciu w seminariach i domach Zgromadzenia Księży Misjonarzy. Almeras nie jest wyłącznym jego autorem; współpracowali z nim inni jeszcze misjonarze-liturgiści. Liczne wydania następne (1670, $1679,1697,1717,1743,1810,1828,1846)$ świadeza wymownie o powodzeniu, jakim cieszyła się tego roidzaju książka we Francji ${ }^{3}$ ).

W pracy swej sięgnął autor do źródeł, jak np. Missale, Caeremoniale episcoporum, czy inne księgi liturgiczne. Uwzględniał najnowsze przepisy, wydawane przez Stolicę Apostolską, a odnoszące się do liturgii względnie ceremonii kościelnych. $Z$ autorów uwzględnił Almeras i jego współpracownicy głównie klasycznych liturgistów, w pierwszym rzędzie prace barnabity Bartłomieja Gavanti'ego (Gavantus, 1569 - 1638). Dzieło jego: „Thesaurus Sacrorum Rituum sive Commentaria in rubricas Missalis et Breviarii Romani“", należało w XVII w. do podstawowych w dziedzinie liturgii i cieszyło się dużym powodzeniem. Pracę swoją

1) Zob. Cholewa $F$., Św. Wincenty a Paulo a śpiew kościelny, Meteor, dwumiesięcznik kleryków Kisięży Misjonarzy, Kraków 1937, s. $76-86$.

$\left.{ }^{2}\right)$ Recueil des principales circulaires des supérieurs généraux de la Congrégation de la Mission, Parris 1877, I. s. 29.

3) Rosset E., Notices bibliographiques sur les écrivains de la Congrégation de là Mission, Angoulême 1878, s. 243 n, 
dedykował Gavanti pap. Urbanowi VIII, który wezwał go do współpracy nad reformą brewiarza $\left.{ }^{4}\right)$. Nowe wydanie przygotował i uzupelnił w latach 1736-1740 z polecenia kard. Lambertini'ego (późniejszego pap. Benedykta XIV) teatyn Kajetan Merati $\left.(\dagger 1745)^{5}\right)$.

Według ks. F. Śmidody przekładu omawianego dzieła ks. Almeras dokonał $z$ francuskiego ks. Michał Barszczewski, superior misjonarzy i rektor seminarium duchownego w Chełmnie, który położył duże zasługi na polu liturgii i krzewienia śpiewu liturgiczno-kościelnego $\left.{ }^{6}\right)$. Nie ma o Barszczewskim jako o tłumaczu żadnej wzmianki ani w Pamiętnikach ks. Kamockiego i ks. Perboyre'a ${ }^{7}$ ), nie zna go również ks. E. $\left.\operatorname{Rosset}^{8}\right)$. Ten ostatni natomiast wspomina o ks. Józefie Maszterowskim (1722-1767), specjaliście w dziedzinie liturgii. Tłumaczył on $\mathrm{z}$ francuskiego (nie wspomina na jaki język) „Manuel des cérémonies“ i opracował jakiś bliżej nieznany rytuał do użytku Kościoła w Polsce ${ }^{9}$ ). Naszym zdaniem tłumaczem wspomnianego podręoznika liturgicznego jest nie Michał Barszczewski, ale Józef Maszterowski. Utwierdził nas w tym przekonaniu list Maszterowskiego (bez daty), pisany do episkopatu polskiego, w którym prosi o pomoc pieniężną. Wyraźnie. w nim zaznacza, że powierzano mu wydanie ceremoniału do użytku seminariów $\left.{ }^{10}\right)$. Nie wiemy, jaka była odpowiedź episkopatu i czy otrzymał jukąś pomoc pieniężną. Wiemy natomiast, że ,Manuale Caeremonia-

$\left.{ }^{4}\right)$ Pastor L., Geschichte der Päpste, t. XIII, 2, Freiburg i. B. 1929, s. 899.

$\left.{ }^{5}\right)$ Zob. Encyklop. Kość., VI. s. 59.

6) Smidoda F. ks., Barszozewski Michał, art. w Pol. Słowniku Biogr. I, s. 309.

7) La Congrégation de la Mission en Pologne, Mémoires de la Congrégation de la Mission, I. Paris 1863.

8) Notices bibliographiques, j. w.

$\left.{ }^{9}\right)$ Rosset pisze o Maszterowskim: „Très-versé dans les différentes branches de la science ecclésiastique, il affectionnait specialement la liturgie et la connaissait à fond". Notices bibliographiques, s. 184. Zob. również wspomnienie o ks. Maszterowskim u Kamockiego-Perboyre'a, Mémoires, I. s. 247.

10) „Commissa est mihi cura a Superioribus meis edendi Librum Caeremoniarum Romanarum seu ipsam praxim Ecclesiarum Urbis Romae ad usum Seminariorurm, jamque accelerarem proelo dare, una me res tantum retardet quae operi consumando necessaria est, nempe argentum et aurum non est mihi". List b. d., Arch. Księży Misjonarzy w Krakowie na Stradomíu (AMS). To samo potwierdza nieznany autor nekrologu ks. Maszterowskiego z r. 1772 w słowach: „Zebrał bardzo pilnie Ceremonie kościelne, które od biskupów przyjẹte, do druku są podane. Zaczął był także z niemniejszą pracą układać Rytuał kościołów krajowych do wydrukowania, i już pierwszą część wygotował, ale drugiej śmierć mu nie dopuściła skończyćc. N e k rolog i, nr 9, Rps. w AMS. 
rum" ukazało się w r. 1764 w dwóch tomach w drukarni Księży Misjonarzy w Chełmnie.

Tłumacz dedykował swą pracę biskupowi wileńskiemu ks. Ignacemu Massalskiemu, wychowankowi seminarium świętokrzyskiego i wielkiemu przyjacielowi misjonarzy polskich. Ks. Maszterowski był wówczas superiorem i profesorem seminarium gnieźnieńskiego (1754 do 1762). Przeniesiony następnie do Warszawy, zetknął się tam z biskupem Massalskim, który chciał go mieć profesorem w seminarium wileńskim ${ }^{11}$ ), od niedawna kierowanym przez misjonarzy. Prawdopodobnie więc bp Massalski, znany ze swej działalności kulturalnej, pospieszył z pomocą materialną ks. Maszterowskiemu.

Z kolei przypatrzmy się treści obydwu tomów. Schematycznie przedstawia się treść ogólna książki następująco:

Tomus I. pars I. De missa privata

pars II. De missa solemni

pars III. De officio divino

pars IV. De variis caeremoniis particularibus

Tomus II. pars I - in qua agitur de cujusque ministri officiis seorsim

pars II. De caeremoniis principalium festorum per annum.

Pierwsze dwie części tomu pierwszego traktują o Mszy św. W pierwszej części jest mowa o Mszy św. cichej ${ }^{12}$ ). Autor wyjaśnia szczegółowo części Mszy św., tłumacząc ceremonie, które kapłan winien zachować, od przygotowania do mszy począwiszy, a skończywszy na dziękczynieniu. Osobno objaśnia ceremonie zwykłej mszy cichej, a osobno odprawianej w obecności np. kardynała, biskupa lub panującego. Omawia również ceremonie, obowiązujące kapłanów, asystujących biskupowi przy cichej Mszy św.

W drugiej części tomu pierwszego rozprawia autor o Mszy św. uroczystej. Obok wyjaśnień i komentarzy, przeznaczonych dla celebransa, znajdujemy dokładny opis ceremonij dla diakona, subdiakona i niższej asysty ${ }^{13}$ ). Osobny rozdział poświęcił unoczystej Mszy św. z wy-

11) Kamocki-Perboyre, Mémoires, I. s. 246. W dedykacji podpisani są ,pres:yteri Congregationis Missionis".

12) Manuale Caeremoniarum, I. 1-129.

13) Tamże, I, 130—208, 
stawieniem Najśw. Sakramentu i ,coram Episcopo dioecesano extra Ecclesiam suam cathedralem" $\left.{ }^{14}\right)$.

Trzecia część mówi ,,de officio divino“. Autor zajimuje się w niej wyjaśnieniem ceremonij kościelnych odnoszących się do uroczystych nieszporów ${ }^{15}$ ), po czym umieścił krótki komentarz do brewiarzowego completorium $\left.{ }^{16}\right)$. Kolejno przechodzi do komentowania i tłumaczenia ceremonij uroczystych nieszporów z wystawieniem Najśw. Sakramentu i nieszporów, odprawianych w obecności biskupa ,extra suam Ecclesiam cathedralem" $\left.{ }^{17}\right)$. Na dalszych stronicach tejże ozęści znajduje czytelnik wyjaśnienia innych cześsi officium, jak matutinum, officium defunctorum, nieszporów pro defunctis ${ }^{18}$ ).

Bardziej szczegółorwymi kwestiami zajmuje się ostatnia część zawarta w pierwszym tomie. Autor opracował w niej ceremonie, odnoszące się do chóru w czasie Mszy św. uroczystej i w czasie nieszporów ${ }^{19}$ ). Zakończenie tomu poświęcone jest takim funkcjom, jak: de aspersione aquae benedictae, de thurificatione, de pace, de communione generali, de expositione Sanctissimi Sacramenti, de oratione quadraginta horarum, de processionibus, de absolutione pro defunctis, de exsequiis seu sepulturis ${ }^{20}$ ).

Drugi tom „Manuale“ w opracowaniu i przekładzie ks. Maszterowskiego poświęcony jest poszczególnym urzędom przy sprawowaniu świętych czynności (cz. I) i wyjaśnianiu ceremonij ważniejszych świąt (cz. II). W pienwszej części skreślił tłumacz obowiązki ceremoniarza, kościelnego i celebransa przy różnych, w pierwszym tomie omówionych czynnościach. Następnie wytłumaczył ceremonie, wykonywane przez diakona, subdiakona oraz asysty niższej i kantorów ${ }^{21}$ ). W dalszym ciągu (cz. II) daje liturgiczny komentarz ważniejszych świąt kościelnych. Rozpoczyna od Adwentu i kolejno wyjaśnia ceremonie wigilii i świąt Bożego Narodzenia, Epifanii, Matki Boskiej Gromnicznej, Popielca, Niedzieli Palmowej, Ciemnych Jutrzni, W. Czwartku, W. Piątku

14) Tamże, I. 208-222.

15) Tamże, I. 223-240.

$\left.{ }^{16}\right)$ Tamże, I. 240-243.

17) Tamże, I, 243-248.

${ }^{18)}$ Tamże, I. 248-264.

19) Tamże, I. 264-297.

$\left.{ }^{20}\right)$ Tamże, I. 297-380.

21) Tamże, II. 1-240. 
(uwzględniając przy tym zwyczaje polskie), W. Soboty, Wielkiejnocy, wigilii i świąt Zesłania Ducha Świętego i Bożego Ciała ${ }^{22}$ ).

Jak z tego pobieżnego szkicu widać, obejmował podręcznik Maszterowskiego najważniejsze zagadnienia, dotyczące liturgii. Uwzględnił przy tym zwyczaje polskie. Ze względu na swoje syntetyczne ujęcie całości i charakter podręcznikowv był on używany $\mathrm{z}$ końcem XVIII i w ciągu pierwszej połowy XIX wieku we wszystkich prawie zakładach teologicznych w Polsce. Z zachowanego wykazu archiwalnego wynika, że $\mathbf{z}$ „,Manuale Caeremoniarum“ uczono w następujących seminariach duchownych: św. Jana i św. Krzyża w Warszawie, w Włocławku, Lublinie, Płocku, Sejnach, Tykocinie i Sandomierzu ${ }^{23}$ ). Ponieważ wykaz ów pochodzi z pierwszej połowy XIX w., przeto nie obejmuje seminariów, pozostających pod zaboren pruskim. Książka, wydana w Chełmnie, była używana z całą pewnością w seminarium chełmińskim i zapewne w seminariach gnieźnieńskim i poznańskim. Można tėz przypuszczać, że dzięki poparciu bpa Massalskiego była w użyciu także w Wilnie. O powodzeniu, jakim cieszył się podręcznik ks. Maszterowskiego, świadozy chociażby drugie jego wydane warszawskie ${ }^{24}$ ).

\section{2. „HEBDOMADALE STUDIORUM“.}

W formie wykładów i ćwiczeń tygodniowych, które odbywały się w seminarium świętokrzyskim iw Warszawie, ukazało się ,Hebdomadale studiorum seu rudimenta theologica loco exercitiorum hebdomadalium ad usum Seminarii Varsaviensis S. Crucis concinnata" (Varsaviae 1805) Autorem tego krótkiego podręcznika jest profesor hermeneutyki, hi-

22) Tamże, II. $241-372$.

$\left.{ }^{23}\right)$ Wykaz dzieł, podług których wykładane są w Seminariach Diecezjalnych nauki (b. m. i r.) AMS. - Ks. St. Chodyński, (Seminarium włocławskie, Włocławek 1904, s. 149) pisze: „Do wykładu, opróoz ksiąg kościelno-liturgieznych, używano Manuale Caeremoniarum (Vars. et Culmae 1819, 1842), z odmianą jednak dość znaczną dla zachowania miejsçowych zwyozajów, których kapituła najmocniej przestrzegała i do nich stosować się poleciła“. Daty powwyższe są nieścisłe. Pierwsze bowiem wydanie ukazało się, jak wspommianı, w r. 1764. II wydanie przygotowali do druku misjonarze świętokrzyscy w Warszawie i tam się té̇ ukazało, t. I. w r. 1842, t. II, uprzednio w r. 1819. Obydwa wydania posiada biblioteka Księży Misjonarzy w Krakowie na Stradomiu. Drugi tom 2 wydania opracowal prawdopodobnie ks. Pawel Rzymski.

${ }^{24}$ ) Estreicherowi przekład „Manuale Caeremoniarum“ ks. Maszierowskiego jest nieznany. Podaje w bibliografii tylko jego „Propositiones theologicae in Ecclesia S. Crucis in praesentia plurium magnatum oppugnatae die 14 octobris 1747 , in fol. k. 7 . 
storii kościelnej i teologii pastoralnej w wspomnianym zakładzie teologicznym, ks. Ignacy L a w s (1761-1843), pochodzący z Warmii. Zawód nauczycielski rozpoczął w Warszawie; następnie był superiorem misjonarzy w Gdańsku, skąd przeniósł się na profesora do seminarium chełmińskiego ${ }^{25}$ ).

Autor dzieli swój zarys na kilka części. Część pierwsza podaje podstawowe wiadomości z patrologii. Ks. Laws zatytułował ją ,Manuductio ad patrologiam, quam professor historiae ecclesiasticae in Seminario Varsaviensi ad S. Crucem in adminiculum et ad SS. Patrum studium auditoribus suis lubenti animo obtulit die 4. 7-bris 1804 anno" (s. 1-27). Druga część dziełka, to „Theologia pastoralis ad usum Seminarii Varsaviensis apud sanctam Crucem contracta" (s. 28-97), a w niej rozdział praktyczny ,de Sacramentorum administratione“ (s. 56-71). Wynika stąd, że sprawę administrowania sakramentów wykładał autor łącznie z teologią pastoralną, a nie przy liturgice, jak to współcześni często czynili. Do studium Pisma św. i liturgiki służyła trzeoia część podręcznika, zatytułowana: ,Hermeneutica Veteris et Novi Testamenti nec non Liturgica Missalis et Psalmodica (w tym hermeneutyka, s. 1-138); liturgika. s. $\left.139-216)^{26}\right)$.

Dla liturgii ważne są w książce Lawsa rozdziały: 1) de Sacramentorum administratione i 2) liturgica. Pierwszy rozdział ma charakter praktyczny $\dot{i}$ wcielony został do traktatu $z$ teologii pastoralnej. Liturgika Lawsa dzieli się na dwie części: a) Liturgica de ritibus tractans, speciatim vero de missa, cursus primus (s. 139-182) i b) Psalmodica, cursus secundus et pars secunda liturgicae (s. 183-216).

Przy pisaniu swego „Hebdomadale“ korzystał Laws z dziel znaczniejszych liturgistów, jak kard. Bony, Bouquillota i Gavanti'ego i do tych autorów odsyła czytelnika ${ }^{27}$ ). Dobrze znany był mu równiė̇ łaciński przekład Maszterowskiego — „Manuale Caeremoniarum“. Podręcznik Lawsa ma inny charakter. O ile praca Maszterowskiego była poważną pozycją w naszej literaturze liturgicznej i dawała alumnom w seminariach należyte w tym względzie przygotowanie, o tyle zarys ks. Lawsa przynosił niejako skrót dla końcowych egzaminów. $Z$ podziału traktatu liturgicznego Lawsa wynika, że liturgikę czyli rubrum wykładano

${ }^{25)}$ Zob. art. ks. St. Chodyńskiego w Encykl. Kość. XII. s. 16 n.

$\left.{ }^{28}\right)$ Schletz A. ks., Działalność naukowo-oświatowa ks. Józefa Jakubowskiego, Lwów 1939, s. 25; tenże, Józef Jakubowski, żołnierz i kapłan, Kraków 1945, s. 142. 27) ,Ad ampliorem eruditionem in re liturgica comparandam legi possunt cardinalis Bona, Bouquillot, Gavantus“. Laws, Hebdomadale studiorum, 5 alb. 
wówczas w seminarium świętokrzyskim przez dwa lata. W pierwszym roku przerabiano liturgię Mszy św., w drugim zaś psalmodię ${ }^{28}$ ).

Ks. Laws nie ograniczył się w swej książce wyłącznie do komentarza Mszy św. Zaletą jego wykładu było, że uwzględniał momenty historyczne, przedstawiając krótko rozwój obrzędów mszalnych i t. p. Druga część podawała alumnom wiadomości o brewiarzu i officium brewiarzowym.

Nie mamy pod ręką żadnych spisów, w których seminariach duchownych - poza seminarium świętokrzyskim w Warszawie - podręcznik Lawsa był używany. Ze względów praktycznych i dzięki swej zwięzłości mógł służyć nie tylko klerykom po seminariach, ale także księżom w duszpasterstwie oddać pewne usługi. Trzeba i ten moment podkreślić, że książka Lawsa nie była żadnym tłumaczeniem z obcego języka, ale podręcznikiem oryginalnym i jako taki stanowił pozycje w naszej polskiej literaturze teologicznej ${ }^{29}$ ).

\section{3. ,RUBRICAE BREVIARII E'T MISSALIS“.}

Duże zasługi na polu teologii polskiej położył na przełomie XVIII i XIX-go wieku pierwszy wizytator prowincji litewskiej Zgromadzenia Księży Misjonarzy i długoletni profesor nauk teologicznych ks. dr Andrzej Pohl $\left(\dagger\right.$ 1820) $\left.{ }^{30}\right)$. Obok podręczników dogmatyki (1808/09)

${ }^{28)}$ Hebdomadale studiorum, s. 139, 183; zob. té̇ Bączkowicz, Z dziejów Domu Stradomskiego, Rocznilki obydwóch Zgromadzeń św. Wincentego a Paulo, Kraków 1915 , s. 139 .

$\left.{ }^{29}\right)$ Ks. Laws interesował się również sprawami biblijnymi. Oprócz traktatu: „Hermeneutica Veteris et Novi Testamenti“, zawartym w Hebdomadale, jest on autorem drugiej pracy p. t.: „Porozdzielane $i$ objaśnione niedzielne i świąteczne Ewangelie, slużace kaplanom do używania" (Warszawa 1787); drugie wydanie ukazało się we Lwowie w roku 1820 por nieco zmienionym tytułem: ,Ewangelie porozdzielone $i$ objaśnione niedzielne $i$ swiateczne służace katechistom do użyuania w cesarsko-królewskich państwach".

${ }^{30}$ ) Ks. Andrzej Pohl, ur. 30. XI. 1742 w Lidzbarku (Heilsbergu) w dzisiejszym woj. olsztyńskim. W r. 1759 wstąpił do Zgromadzenia Księży Misjonarzy w Warszawie. W r. 1764 został profesorem Seminarium Duchownego w Wilnie. W latach 1767-1776 pracował w Siemiatyczach, a następnie (1776-1782) jako asystent i profesor seminarium świętokrzyskiego w Warszawie. Superiorem wileńskim został w roku 1782, a po r. 1796 do swej śmierci piastował godność wizytatora prowincji litewskiej misjonarzy. Jest autorem licznych prac z dziedziny teologii, ascetyki i kaznodziejstwa. 
i teologii moralnej (1809/10), używanych w pierwiszej połowie XIX w. we wszystkich prawie seminariach duchownych w Polsce ${ }^{31}$ ), a także na wschodzie $^{32}$ ), był Pohl autorem dzieła z zakresu liturgii, wydanym dopiero po jego śmierci. Ukazało się ono w Wilnie w r. 1821 p. t.: „Rubricae Breviarii et Missalis Romani juxta decreta Sacrae Rituum Congregationis, mentemque gravissimorum in re liturgica authorum dilucida methodo explicatae atque opportunis animadversionibus illustratae, opus in duas partes divisum, viris ecclesiasticis perutile ac necessarium ${ }^{\text {"6 }}$ (t. I. s. $388+4$ nlb, t. II. s. $230+2$ nlb.).

Podobnie jak wizytator warszawski ks. Józef Jakubowski był reformatorem seminariów duchownych w Polsce na początku XIX wieku ${ }^{33}$ ), tak znów ks. Pohl jako wizytator prowincji litewskiej przyczynił się do odrodzenia nauk $w$ seminariach duchownych tej prowincji. Zwołany przez Pohla w r. 1814 do Wilna konwent misjonarzy prow. litewskiej poruszył szereg ważnych zagadnień, związanych $\mathrm{z}$ oświlatą, jak np. sprawa seminariów duchownych, małych seminariów i szkól parafialnych. Baczną uwage zwracano na profesorów seminaryjnych, ich poziom naukowy i moralny ${ }^{34}$ ). W planie nauk seminaryjnych kładziono nacisk $\mathrm{m}$. in. na przedmioty, związane $\mathrm{z}$ liturgią, jak administrowanie Sakramentów, śpiew liturgiczno-kościehny i ceremonie ${ }^{35}$ ). Co więcej. Przyszłych kandydatów do stanu kapłańsko-misjonarskiego zaczynano już w seminarium internum (nowicjacie) przygotowywać do czekających ich zadań. W tym celu miano im wykładać m. in. ceremonie, uczyć śpiewu kościelnego i języka łacińskiego ${ }^{36}$ ).

Dla lepszego udostępnienia wiedzy liturgicznej przyszłym adeptom do kapłaństwa napisał Pohl szereg prac o charakterze syntetycznym. Do tego rodzaju prac należą: „Ceremonie biskupie“ w jednym tomie

31) Wykaz dzieł, j. w., AMS.

32) Kis. Pohlowi jako wizylatorowi prowincji litewskiej podlegały nastepujące seminaria duchowne: wileńskie, białostockie, żmudzkie (w Worniach), mohylowskie, krasławskie i żytomierskie

$\left.{ }^{33}\right)$ Schletz, Józef Jakubowski, s. 140.

${ }^{34)}$ „Reverendissimus Visitator, cum consilio Consultorum Provinciae determinabit et designabit Professores, in quantum fieri potest, in suis respective objectis sollidissimos". D e c r e t a in Conventu Provincionali Congr. Missionjis Prov. Ljthuanae in Domo Vilnensi ad montem SS-mi Salvatoris... Anni 1814 celebrato, (Wilno 1814), c. XIV, p. C4.

$\left.{ }^{35}\right)$ Decreta, c. XIV, p. C.

$\left.{ }^{36}\right)$ Decreta, c. XIV, p. C. 
(niedokończone) ${ }^{37}$ ), „Wykład brewiarza“6 ${ }^{38}$ ), który włączył zapewne później do zbioru „Rubricae Breviarii et Missalis“. Pierwsza praca pozostała w rękopisie i znajdowała się dawniej w Archiwum Księży Misjonarzy w Wilnie. „Rubricae“ pochodziły z wykładów ks. Pohla i ukazały się w druku wkrótce po śmierci autora. Wykończył swe dzieło za życia, jak to wynika $\mathrm{z}$ aprobaty cenzora, ks. Jana Niedźwieckiego z r. 1819. Książka jego ma charakter podręcznikowy. Autor daje w niej pozytywny wykład brewiarza i mszału.

Pierwszy tom traktuje ogólnie de divino officio, de officio duplici, semiduplici, simplici, po czym wyjaśnia autor nabożeństwa niedzielne, ferialne, wigilie świąt i nabożeństwa świąteczne. Zanim przechodzi do poszczególnych części brewiarza, wyjaśnia wpierw zagadnienia związane $\mathrm{z}$ officium brewiarzowym, jak np. de occurentia festorum, de concurentia festorum, podając zasady ogólne (tres regulae circa concurentiam festorum observandae).

Po omówieniu poszczególnych części brewiarza, po których dodał Pohl dekrety św. Kongregacji z lat 1683, 1743 i 1745, przeszedł do wykładu officium apostołów, ewangelistów, męczenników, dziewic itd. Dość dużo miejsca poświęcił mszom św. za zmarłych. Po mszach żałobnych dał autor wykład poszczególnych części Mszy św. Pierwszy tom kończy się wiadomościami o ważniejszych uchybieniach, które przy odprawianiu Mszy św. przydarzają się i o puryfikacji puszki. Ostatni rozdział dodatkowy wspomina o dekretach kongregacji rzymskiej.

Drugi tom poidaje obszerny schemat świąt nieruchomych i Proprium Sanctorum, ułożonych chronologicznie według dni i miesięcy na sposób rubryceli (s. 1-80). Dodał autor równocześnie dokładny komentarz we formie przypisów, umieszczonych u dołu stronicy. Na dalszych kartach tego tomu, przechodząc cały rok kościelny - tłumaczył autor jego znaczenie pod względem liturgicznym. Komentarz swój rozpoczął od niedziel po Trzech Królach. Kolejno omówił potem niedziele od siedemdziesiątnicy poprzez Popielec i Wielki Post, więcej miejsca poświęcając Wielkiemu Tygodniowi, oraz niedziele i święta aż do Adwentu włącznie.

Po wykładzie roku kościelnego umieścił Pohl w swym podręczniku ważniejsze dekrety rzymskie $\mathrm{z}$ XVIII w., odnoszące się do liturgii, a także najnowsze ${ }^{39}$ ). Osobno uwzględnił zwyczaje, panujące w katedrze

37) Stankonowicz, Pamiątka życia śp. JX. Andrzeja Pohla, Wilno 1821, s. 22.

${ }^{38)}$ Rosset, Notices bibliographiques, s. 201.

a9) Rubricae, II. s. $123 \mathrm{nn}, 140 \mathrm{nn}$. 
wileńskiej, jak np. św. Kazimierza ${ }^{40}$ ), św. Stanisława, czy aniwersarzy ${ }^{41}$ ). Nadto dla polskich zwyczajów cenne są jego uwagi o Mszy św. roratniej, ułożone na podstawie ordynacji biskupa wileńskiego Jana Kossakowskiego z r. $\left.1808^{42}\right)$.

W dodatkach do swych, ,rubryk" dał autor szereg arłykułów, jak: de consecratione ecclesiae; de patrono et titulo ecclesiae; de patrono loci, regni, dioecesis; de festis Sanctorum; de officiis, quae semel in mense aut in hebdomada celebrantur. Kończy zaś swe dzieło o relikwiach Swiętych ${ }^{43}$ ).

Przeglądając dawne spisy przedmiotów, wykładanych w seminariach duchownych, znajdujemy w wykazie 3 przedmioty, które związane były z liturgią i nawzajem się uzupełniały: 1) ,,rubrum z liturgią“, 2) ,obrządki kościelne" i 3) „,́piew kościelny“. Jeżeli „Manuale Caeremoniarum" ks. Almeras'a w przekładzie Maszterowskiego było podstawowym przy wykładzie ,obrządków" czyli ceremonij, to znów dzieło Pohla dawało alumnom przy wykładzie ,,rubrum“ z liturgiką elementarne z tej dziedziny wiadomości. Stąd obydwa podręczniki były potrzebne i pożyteczne.

W pierwszej połowie XIX w. podręcznik Pohla przyjął się w kilku seminariach, mianowicie: w seminarium motropolitalnym św. Jana w Warszawie, św. Krzyża w Warszawie, we Włocławku, Lublinie i Płocku ${ }^{44}$ ). W seminarium włocławskim przetrwał do r. 1890 t. j. do wprowadzenia podręcznika de Herdta „Sacrae liturgiae praxis“, lecz już po dwóch latach wprowadzono na jego miejsce „Ceremoniat pro rafialny" ks. A. Nowowiejskiego $\left.{ }^{45}\right)$. O książce ks. Pohla trzeba to powiedzieć, że była ona poważniejszą pozycją w teologii polskiej i pierwszym na poziomie akademickim wydanym podręcznikiem do nauki liturgii w Polsce.

$\left.{ }^{40}\right)$ Tamże, II. s. 19, 21.

41) Tamże, II. s. 146-151. Zob. też Kurczeuski J. ks., Kościół zamkowy czyli katedra wileńska, Wilno 1910 , II. s. $328-330$.

$\left.{ }^{42}\right)$ Rubricae, II. s. 79 n.; Kurczewski, dz. cyt. II. s. 330.

${ }^{43}$ ) Zainteresorwania ks. Pohla słły także w kierunku biblijnym. Kisiegi Pisma św. uważał za podstawowe w teologii. Pierwsza praca z tego zakresu odnosiła się do egze. gezy biblijnej i przeznaczona była dla alumnów. Ukazała się w ll. 1810-1811 w 5-ciu tomikach p. t.: Scriptura Sacra per quaestiones exposita, responsionibus explicata, contra incredulos defensa, opus ad sciendas et intelligendas divinas litteras utilissimum. Nadto jest Pohl autorem anonimowego pisma p. t.: Rozprawa czyli wolno wszystkim béz braku czytać księgi Pisma św. w językach krajowych... (Wilno 1817). Por. Bieliński J., Uniwersytet wileński, Kraków 1899-1900, II. s. 605 n.

${ }^{44)}$ Wykaz dzieł, j. 'w., AMS.

$\left.{ }^{45}\right)$ Chodyriski, Seminarium włocławskie, s. 149. 


\section{4. "WYKLAD OBRZĘDÓW KOŚCIELNYCH".}

Autorem pierwszego podręcznika liturgicznego w języku polskim, klóry zaszczyt przynosi teologii polskiej — był, ks. Paweł Rzymski $(1783-1833)$. Należał on niewątpliwie do wybitnicjszych profesorów teologiii w pierwszej ćwierci XIX stulecia. Szkołę ukończył u misjonarzy w Tykocinie. W r. 1803 wstąpił do misjonarzy przy kościele św. Krzyża w Warszawie $\left.{ }^{46}\right)$. Zawód profesorski rozpoczął jeszcze przed święceniami kapłańskimi, a po wyświęceniu (1808) był przez dwa lata profesorem hermeneutyki, filozofiii i języków hebrajskiego i greckiego. Sześć lat następnych (1810-1816) przepędził w Poznaniu, gdzie w seminarium duchownym wykładał teologię, język hebrajski ${ }^{47}$ ) i zdaje się także historię. O jego działalności w Poznaniu pisze ks. Gorzkiewioz, że była dlań ,,szkołą własnego ówiczenia, zgłębienia nauk i poznawania ludzi“" i że istniały dwie dla niego rzeczy - książka i Bóg. Pozostawił z tego okresu historyczny opis seminarium, oraz uporządkował bibliotekę $\left.{ }^{48}\right)$.

W roku 1816 przeniósł go ówezesny wizytator, ks. Józef Basiński do Warszawy i tu powtórnie wykładał w seminarium św. Krzyża. Niebawem po powstanru uniwersytetu warszawskiego rozpoczął ks. Rzymski wraz z drugim misjonarzem, ks. Michałem Symonowiczem, wykłady na wyḋziale teologicznym. Powierzono mu katedrę Pisma św. i języka hebrajskiego.

Wychowany na teologii Collet'a i przyzwyczajony do surowszych obyczajów nie mógł Rzymski pogodzić się z nowymi prądami, którymi przejęli się profesorowie i studenci teologii. To też wkrótce zrezygnował wraz $z$ ks. Symonowiczem $z$ katedry $\left.{ }^{49}\right)$. Odtąd wylkładał aż do objęcia urzędu wizytatora prowincji (1826) w seminarium świętokrzyskim w Warszawie różne przedmioty teologiczne, jak dogmatyke pastoralną, prawo, hermeneutykę, a w r. 1821 historię Kościoła i śpiew kościelny.

46) Catalogus seminaristarum Seminarii Interni Congr. Miss. Domus Varsaviensis, pod r. 1803, Rps. AMS.

${ }^{47}$ ) Gorzkiewicz M. ks., List okólny z d. 1. I. 1834 (nekrolog), s. 1 n., druk w AMS. Zob. też art. ks. Ł. J(anczaka) o ks. Rzymskim w Encylkl. Kość. t. XXIV, s. 107 n.; Kalla St. ks., Seminarium poznańskie pod rządami ks. Krzywańskiego, Roczniki ob. Zgromadzeń św. Wincentego a Paulo 1914, s. 195; Encykl. Powsz. Orgelbranda, t. XXII, s. 743 .

${ }^{48)}$ Gorzkiewicz, List, j. w., s. 2.

49) Kamocki-Perboyre, Mémoires, I. s. 483; Chodyński St. ks., w Encyklop. Kość. t. XXV, s. 82; Godlewski M. bp, Epizod z dziejów Seminarium Głównego w Warszawie w 1831 roku, Collectanea Theologica, XXI (1949), s. 17-19. 
Nadto był w tym okresie egzaminatorem prosynodalnym i cenzorem ksiąg religijnych ${ }^{50}$ ). Równocześnie zamianował go ks. wizytator Symonowicz prefektem biblioteki i dyrektorem drukarni misjonarskiej ${ }^{51}$ ).

Poświęcił się teraz pracy naukowej. Najpierw wydał kancjonał dla duchowieństwa p. t. Cantionale Ecclesiasticum (Warszawa 1822). używany w seminariach duchownych i po parafiach. Był to pierwszy w pojęciu dzisiejszym kompletny kancjonał, wydany w Polsce. Alumni w seminariach nie posiadali dotychczas książki, któraby zajęła się teorią chorału. Kancjonał Rzymskiego rzuca pewne smugi światła na ówczesną metodologię śpiewu gregoriańskiego, bo podał w swym wykładzie ,Instructio ad cantum choralem“, umieszczonej we formie dodatku ${ }^{59}$ ). Zawiera nadto wszystkie ważniejsze śpiewy z tekstami, związane $z$ życiem liturgicznym, a więc: aspersje, procesje, ważniejsze pieśni i hymny, także polskie; w drugiej zaś części officium defunctorum, egzekwie, procesje na dzień zaduszny. Dodatkowo zawiera książka różne objaśnienia, odnośnie do ceremonij i rubryk.

O powodzeniu, jakim cieszył się tego rodzaju kancjonał, świadczą liczne następne wydania $\left.(1825,1833,1846,1856)^{53}\right)$. Wydanie $z$ r. 1856 z osobnym dodatkiem przygotował do druku ks. Andrzej Dorobis, wizytator misjonarzy warszawskich ${ }^{54}$ ). Ostatnie wydanie kancjonału wyszło w przeróbce ks. K. Waberskiego w r. $1882^{55}$ ).

Drugim dziełem ks. Rzymskiego $z$ zakresu liturgii jest jego ,Wyklad obrzędów kościelnych historyczny $i$ duchowny $z$ historii kościelnej, liturgii, $z$ dzieł przez znakomitych autorów o niej napisanych niemniej $z$ ducha tychíe obrzędów wyczerpniony", (Warszawa 1828 , s. 8 nlb $+349+3$ nlb.) Dedykował je ancybiskupowi warszawskiemu P. J. Woroniczowi. W przedmowie do ,łaskawego czytelnika“ zaznaczył autor, że tak opracował swe dziełko ,mogące wprawdzie usłużyć i świeckim osobom, które mają chęć znać i rozumieć święte obrzędy, lecz szczególniej młodzieży duchownej, w seminariach do służby Bożej sposobiącej się, potrzebne $\left.{ }^{666}\right)$.

$\left.{ }^{50}\right)$ Ordo divini officii archidioec. Varsaviensis 1817-1821; Catalogus universi cleri archidioec. Varsaviensils $1822-1826$.

51) Gorzkiewicz, List, j. w., s. 2.

${ }^{52}$ ) Feicht H. ks., X. Michał Marcin Mioduszewski, Księga Pam. ku czci Prof. A. Chybińskiego, Kraków 1930, s. 70.

53) Chodyński, dz. cyt., s. 151.

$\left.{ }^{54}\right)$ Dorobis A. ks., Xięga do zapisywania ważniejszych wypadków w Zgromadzeniu, s. 64, Rps. AMS.

$\left.{ }^{55}\right)$ Chodyński, dz. cyt., s. 151.

$\left.{ }^{56}\right)$ Wykład obrzędów, s. 8 nlb. 
Autor podzielił swe dzieło na 6 części, obejmując w ten sposób mniej więcej całość zagadnienia. W pierwszej części rozprawia ,o kościołach, ich częściach, sprzętach, ozdobach, naczyniach i ubiorach kościelnych". Rzeez ujął historycznie i opisowo i w ośmiu rozdziałach zajął się k/westią kościołów w pierwszych trzech wiekach, wyglądem zewnętrznym i wewnętrznym świątyń, a w związku z tym ostatnim oltarzami, obrazami, sprzętem liturgicznym, szatami liturgicznymi, wreszcie omówił dzwony ${ }^{57}$ ). Druga część poświęcona jest ,publicznemu i powszechnemu nabożeństwu“. W sześciu rozdziałach wytłumaczyl Rzymski officium brewiarzowe (jutrznię, godziny mniejsze, nieszpory i komplete, oraz osobno psalmodię, kantyka i hymny); nadto poświęcił kilka uwag śpiewom i muzyce kościelnej, a także językowi liturgicznemu ${ }^{58}$ ).

„Wykład obrzędów Mszy św.“ stanowi trzecią część dzieła Rzymskiego. W pięciu rozdziałach komentował mszę, a w dodatku omówił mszę z asystą, pontyfikalną, cichą, żałobną, dodając uwagi ,o miejscu, czasie i liczbie Mszy św" ${ }^{59}{ }^{59}$. Czwarta część książki poświęcona jest „obrzędom przy sprawowaniu Sakramentów św.", gdzie autor w siedmiu rozdziałach dał komentarz liturgiczny do poszczególnych Sakramentów $\left.{ }^{60}\right)$. O sakramentaliach pisał Rzymski w części piątej, umieszozając na końcu wiadomości „o procesjach i innych praktykach religijnych" $\left.{ }^{61}\right)$. Ostatnią część w „Wykładzie obrzędów“ stanowi traktat o świętach (najobszerniejszy), gdzie w 26 rozdziałach przechodzi po wstępnym omówieniu świąt w ogólności i niedzieli - do świąt od Adwentu do końca roku kościelnego. Po świętach Pańskich dał autor wykład świąt Maryjnych i Świętych Pańskich, Dnia Zadusznego, a kończy książkę wiadomością o różańcu i szkaplerzu ${ }^{62}$ ).

$Z$ uznaniem nadto trzeba podkreślić to, że autor uwzględnil także zwyczaje polskie i obrzędy, uświęcone tradycją i krótkie o nich wzmianki wprowadził do swego wykładu, jak np. o cmenłarzach, roratach, zwyczajach kolędowych, Gorzkich Zalach i in.

Nie wiemy dokładnie, czy się ,Wykład obrzędów“ przyjął w seminariach duchownych, bo ,wykaz dzieł, podług których wykładane są

\footnotetext{
57) Tamże, s. $1-46$.

58) Tamize, s. $47-67$.

59) Tamże, s. 68-132.

$\left.{ }^{60}\right)$ Tamże, s. 133-204.

61) Tamże, s. 204-252.

${ }^{62)}$ Tamże, s. 253-349.
} 
w seminariach nauki“, jaki mamy pod ręką, pochodzi z przed $1828 \mathrm{r}$. Wnioskować jednak można, że przyjął się wśród młodzieży duchownej i cieszył się powodzeniem, o czym świadezą chociażby następne wydania z lat 1837 i 1857. Trzecie wydanie uzupełnil i do druku przygotował wspomniany wyżej ks. Andrzej Dorobis. Wyraźnie wspomniał o tym w swoim pamiętniku pod datą 20 listopada (1856 r.): ,Ukończyłem b. mozolne dziełko: Wykład obrzędów kościelnych, gdzie się po ks. Rzymskim drugie tyle dodało rzeczy pożytecznych, a jeżeli Bóg pozwoli, to się jeszcze lepiej w II tomiku uzupłni. Pracowałem nad tym lat trzy $\left.{ }^{663}\right)$.

Ks. Dorobis wprowadził w nowym wydaniu cały szereg uzupełnień, jak np. cz. III. r. V, ,wykład Mszy św. (w znaczeniu duchowym“ "64) i w dwóch dodatkach o ,porządku liturgii św. Jana Chryzostoma i początku innych liturgij i ksiąg liturgicznych ${ }^{65}$ ). W IV części rozszerzył rozdziały o chrzcie, bierzmowaniu i kapłaństwie. Przy kapłaństwie dodał wiadomości o archiprezbyterach, o znaczeniu święceń, o degradacji. Nadto cenne są wywody Dorobisa o biskupach tytularnych, instytucji dawnych biskupów wiejskich (chorepiscopi), wikariuszach biskupich, ingresie biskupa i instalacji proboszcza $\left.{ }^{66}\right)$. Rozdział o pokucie również uległ znacznym zmianom. Dorobis wprowadził tu szereg rzeczy nowych, historyeznych, jak o pokucie publicznej w starożytności i średniowieczu, o wojnach krzyżowych, o rekoncyliacji, oraz dał wypisy $\mathrm{z}$ dawnych kanonów pokutnych, wyjętych $\mathrm{z}$ ustaw synodalnych, a kończył się wzmianką dłuższą o odpustach i jubileuszu ${ }^{67}$ ). Rozdział o małżeństwie p̉owiększył podaniem wiadomości historyczno-prawnych i o małżeństwie w kościele wschodnim.

W piątej części uzupełnił Dorobis szozegóły Rzymskiego o cmentarzu świętokrzyskim w Warszawie, umieszczając równocześnie wiadomość o dawnych grobach chrześcijan $\left.{ }^{68}\right)$. Przy omawianiu Adwentu (cz. VI. r. III) podał szczegóły o polskich zwyozajach, jak np. „o trąbieniu na ligawkach w czasie adwentowym ${ }^{669}$ ). Uzupełnił także nowymi szczegółami historię pasji Wielkopostnej zw. Gorzkimi Żalami i opisał

$\left.{ }^{63}\right)$ Dorobis, Xiega, j. w., s. 64, AMS.

${ }^{64)}$ Wykład obrzędów, wyd. III., s. 95-101.

$\left.{ }^{65}\right)$ Tamże, s. $109-125$.

68) Tamże, s. 171-176.

${ }^{67)}$ Tamże, s. $177-207$.

${ }^{68)}$ Tamże, s. $251 \longrightarrow 261$.

${ }^{69}$ ) Tamże, s. 303 n. 
zwyczaje, panujące u nas w poniedziałek wielkanocny, zw. Emaus. Książka Rzymskiego kończy się rozdziałem o szkaplerzu. Ks. Dorobis dorzucił kilka myśli o objawieniu z r. 1830 i o Cudownym Medaliku. Od niego pochodzą również rozdziały od XXVII do XXXII, zawierające następujące tytuły: „O rozmyślaniu, rekolekcjach i innych éwiczeniach położności"; „O kanonizacji Świętych“; ,O postach“; „O kalendarzu“; ,O martyrologium i aktach męczenników i o znaczniejszych relikwiach“ $\left.{ }^{70}\right)$.

Oprócz tego zamierzał ks. Dorobis wydać jeszcze drugi tom, który miał być uzupełnieniem ,Wykładu obrzęów" ks. Rzymskiego. Przy końcu III wydania umieścił Dorobis następującą na ten temat uwagę: „Oprócz uzupełnienia wykładu obrzędów w taki sposób, jaki we wstępie zapowiedział, dopełniający ma jeszcze zamiar w czasie sposobnym napisać dodatkowy tomik $\mathrm{z}$ wykładem stopni, praw, ceremonij $\mathrm{i} t$. p. hierarchii kościelnej, tak zachodniej, jak i wschodniej, z opisaniem tıybunałów rzymskich i ich atrybucyj, ze wzmianką o zwyczajach i obyczajach chrześcijan w średnich wiekach, których nie ma Bielski i t. p. Oby Bóg pozwolił zdrowia i czasu. Byłoby to skompletowanie tej reszty artykułów, których książki duchowne, elementarne nie mają $\left.{ }^{61}\right)$.

Zainteresowania liturgiczne okazywał ks. Rzymski nie tylko w okresie profesury w seminarium świętokrzyskim, ale czuwał również nad wiernym wykonywaniem ceremonij kościelnych jako wizytator prowincji. Zasługa jego było, że kazał spisać dawne zwyczaje i przywileje, oraz porządek nabożeństw w kościele św. Krzyża w Warszawie. Obszerny rękopis p. t.: „Pamiętnik dla Kościola Parafialnego Śbiętego Krzyża, spisany roku $1832^{* 7^{72}}$ ) jest także jawnym dowodem pielęgnowania ducha i kultury liturgicznej.

Wkońcu wolno nam wyciągnąć pewne wnioski ogólne. Podręczniki, używane w polskich seminariach duchownych XVIII i XIX stulecia stały na wysokości swego zadania i dawały gwarancję, że młodzież

70) Tamże, s. 388-442.

71) Tamże, s. 442.

73) Rps w zakrystii kościoła św. Krzyża w Warszawie. Na odwrotnej stronie karty tytułowej taki znajdujemy dopisek: „W szafie w zakrystii zachowywany i w potrzebie od braci zakrystianów czytany być ma ten pamiętnik. 12 czerwca 1833 r. X. P. Rzymski, Vis. Congr. Miss." 
duchowna otrzymała w zakresic nauk liturgicznych dostateczne przygotowanie do należytego wypełniania przyszłych obowiązków kapłańskoduszpasterskich.

Ks. Alfons Schletz C. M.

\section{KRÓTKIE TEKSTY BIBLIJNE}

KU CZCI NAJS̃W. SERCA PANA JEZUSA.

1. O SERCU BOGA i JEZUSA.

1 Król. 9, 3:

I rzekł Pan (do Salomona): Oto świętym czynię przybytek, który zbudowałeś, mieszkać w nim każę na zawsze imiení swemu, a moje oczy i moje serce przehywać tam będą po wszyskie dni.

$$
\text { Ps. 32, 11. 19: }
$$

Myśli serca PANA czuwają z pokoleń w -pokolenia, a Jego oko patrzy na tych, którzy Go się boją, którzy wyglądają Jego miłosiendzia, aby ich dusze od śmierci ratował.

\section{Sam 13, 14 (Słowa Samuela o Dawidzie):}

Wybrał sobie Pan mẹża według serca Swego i ustanowił go księciem nad łudem swoim. - Por. Dzieje 13, 22: Znałazłem Dawida, męża według serca swego, kłóry spełniać będzie wszelką wolę moją.

Mat 11, 29 (Siowa Chrystusa):

*...uczcie siẹ ode muie. bom cichy i pokornego serca...

Luk. 1, ij (Słowa Zachariasza do Jana Chrzciciela):

Ty kroczyć będziesz przed obliczem Pana,

by głosić ludowi naukę

o zbawieniu przez grzechów odpuszczenie,

dzięki litościwemu sercu naszego Boga ${ }^{1}$ ),

z którym odwiedzi nas Ten, który wschodzi już na wysokości,

by świecić tym, co siedzą w ciemności, w cieniu śmierci,

by nasze kroki skierować na drogę pokoju.

1) W tekście jest viscera, wnętrzności, który to wyraz jest synonimem do , serca“. 